Peshawar Journal of Psychology and Behavioral Sciences, 2015, Vol. 1, No. 2, 125-136

\title{
Impact of Traumatic Events on University Students Belonging to FATA and Settled Area
}

\section{Sumaira Mehreen ${ }^{1}$ and Madiha Asghar ${ }^{2}$}

\author{
Islamia College Peshawar
}

\begin{abstract}
The aim of the present study was to examine the impact of traumatic event on university students. In this study the students of settled area were compared with students of FATA on impact of event scale. Sample of $\mathrm{N}=200$ university students belongs to settled area and FATA of Khyber Pakhtunkhwa, Pakistan were taken from different universities. Students of settled area $(n=100)$ included 49 male and 51 female students between the ages of 18 and 23 years $(\mathrm{M}=20.50, \mathrm{SD}=1.24)$. And students of FATA $(\mathrm{n}=100)$ included 81 male and 19 female students between the ages of 19 and 23 years $(M=20.58, S D=1.02)$. Convenient sampling technique was used for data collection. Responses of all the students were analyzed with statistical package of social sciences version 20 . The findings of study indicated that the impact of event was high on students belongs to area directly affected by war (FATA) as compared to students of settled area. The level of stress among university students belongs to FATA was higher due to militancy and war in their areas. The results supported the main hypothesis. Further research studies are required to explore the other areas of FATA and to identify the other factors. Limitations of the study for future researches and practice were also discussed.
\end{abstract}

Keywords. Traumatic event, university students, FATA, and settled area

In the post $9 / 11$ era the international strategic and political culture changed. The concept of global Jihad became trendy. Post 9/11 military operation in Afghanistan by American and North Atlantic Treaty Organization (NATO), further expanded to Pakistan's Federally Administered Tribal Areas (FATA) making it the chessboard of great

\footnotetext{
${ }^{1}$ MS Scholar, Department of Psychology, Islamia College Peshawar

${ }^{2}$ Assistant Professor, Department of Psychology, Islamia College Peshawar
} 
power politics. It is a fact that this foreign intervention had become the main catalyst for militancy and this war became a 'bleeding wound' for Pakistan (Hilali, 2013). People living everywhere in Pakistan affected by this war especially people of FATA because, they are frontline fighters.

As youth play important role in the development of a country and Pakistan is one of those countries whose major part of the population comprises of youth. And they play significant role in social and economic development of Pakistan (Faizunnisa \& Ikram, 2004). According to Nawazish (2011) Pakistan has seven crore (66\%) youth population, which is the strength of Pakistan for development, prosperity and technological advancement in national and international levels. So it is very important to know about the role of youth in the country's development (Faizunnisa \& Ikram, 2004). For a developed and prosperous nation and the development of the country there are different factors that contribute towards attainment of goals of prosperity and development one of those factors is education and it has been an important part of society for thousands of years and play most important role in the development of any country, imparting quality education requires healthy, peaceful and stress-free environment.

Stress free or peaceful environment is a condition or period of mutual concord between governments, freedom from disturbing, worrying or repressive feelings, emotions, thoughts or harmony in personal relations. When it is persistent and unmanageable, then it becomes damaging (Timby, 2008).

Stress is a normal reaction to change and it is an enviable and important element of someone life, which helps in learning and growing, also keeps oneself active, alert and goal directed (Fischer, 2013; Videbeck, 2013). Some external forces affect a person and the conditions of that affect are known as stress. The word stress first time used in 1930 and with the passage of time in recent decades it become more popular. And stress can also be defined as a normal reaction of the body (physiological, mental, and emotional) as a mechanism of self-protection and preservation from a stressful event (Stress, 2015).

In student's life, students face various types of stressors. The learning capability and educational performance of the students are affected due to environmental, physical, social, emotional and familial problems (Jaykaran, Bhardwaj, Panwar \& Chavda, 2009). According to 
Gisele (2002) university students face a number of different types of stressful events during their studies (Shaikh et al., 2004).

Whereas University students belong to FATA, Pakistan are more vulnerable to serious stressors due to war against terrorism in their motherland. Threats from terrorist and the possible chances of war may cause helpless feelings and fear. Possible reactions of students due to war and traumatic events can be concerned with incidents related to war and terrorist attacks (Coping with trauma, terrorism \& war, 2014).

This topic is of great importance but there have been very few studies done so far to assess the impact of traumatic event among university students (Ahmad, Mohammad, Ahmed and Sajid, 2014) belongs to FATA. So this study is proposed to compare the impact of traumatic events on university students belong to FATA and settled area. As it is evident from the above studies that numerous war events were experienced by an individual had higher impact on them (Badri, Van den Borne \& Crutzen, 2013).

The study aims to investigate, compare and correlate the impact of traumatic event on university students belongs to FATA and settled area due to the impact of war against terrorism. There is pattern of research conducted so for on the impact of traumatic event on students. However, there is no research found on comparison and correlation of the impact of traumatic event on students belongs to FATA and settled area KPK.

The significance of the research may likely to have dimension, such as:

\section{Objectives}

1. To investigate, correlate and compare the impact of posttraumatic symptoms among university students belongs to FATA and settled area.

2. To find the gender difference in posttraumatic symptoms of students belonging to FATA and settled area 


\section{Hypotheses}

1. Symptoms of posttraumatic stress will be high among students belonging to area directly affected by war (FATA) as compared to those living in non-war (settled) area.

2. Females will be more prone to severity of posttraumatic symptoms as compared to males belonging to FATA and settled areas

\section{Method}

\section{Sample}

The university student belongs to FATA and settled area (Peshawar) was considered as study population. A total of two hundred $(\mathrm{N}=200)$ students of different universities of KPK (settled area) and FATA and were selected in the study. One hundred $(n=100)$ students of settled area included forty-nine $(n=49)$ male and fifty-one $(n=51)$ female students with the age range of $18-23$ years $(\mathrm{M}=20.50, \mathrm{SD}=1.24)$. One hundred $(\mathrm{N}=100)$ students belonging to FATA included eighty-one $(\mathrm{n}=81)$ male and nineteen $(\mathrm{n}=19)$ female students with the age range of 19-23 years $(\mathrm{M}=20.58, \mathrm{SD}=1.02)$. Convenient sampling technique was used for data collection.

\section{Instruments}

\section{Demographic Information (DI)}

The first part of the questionnaire consisted of a general demographic information questionnaire. Information concerning age, gender, educational background, Socio-economic status and residence (FATA/settled area) were collected from this questionnaire.

\section{The Impact of Event Scale (IES)}

Mardi Horowitz, Nancy Wilner, and William Alvarez developed The Impact of Event Scale (IES) in 1979. It's a 15 items four point likert 
scale ranging from 0 to5. Where response for 0 considered "not at al", 1 for "rarely", 3 for "sometimes" and 5 for "often". Which was used to measure the level of stress associated with a specific event and trauma and the impact of that event which currently bother the individual (Steve, 2007).

\section{Procedure}

It was a comparative study conducted in Khyber Pakhtunkhwa (KP), Pakistan. Convenient sampling technique was used in order to distribute the subjects into two groups namely students belong to FATA and Settled area. Subjects were approach individually for data collection at their university and departments. All of the subjects were informed about the purpose of the research and informed consent was taken from them. Demographic information of all the subjects of two groups $(\mathrm{N}=200)$ was obtained. The demographic information sheet and Impact of Event scale was used respectively for the purpose of data collection.

\section{Result}

Table 1

Psychometric Properties of the Impact of Event Scale $(\mathrm{N}=200)$

\begin{tabular}{|c|c|c|c|c|c|c|}
\hline \multirow[t]{2}{*}{ Scale } & \multirow[t]{2}{*}{$\mathrm{M}$} & \multirow[t]{2}{*}{ SD } & \multirow[t]{2}{*}{$\alpha$} & \multicolumn{2}{|c|}{ Range } & \multirow[t]{2}{*}{ Sken } \\
\hline & & & & Potential & Actual & \\
\hline \multicolumn{7}{|c|}{ Total Sample } \\
\hline IES & 37.51 & 10.995 & .783 & $0-75$ & $0-64$ & -.399 \\
\hline \multicolumn{7}{|c|}{ Students of Settled Area } \\
\hline & 34.76 & 10.47 & .77 & $0-75$ & $0-61$ & -.011 \\
\hline \multicolumn{7}{|c|}{ Students of FATA } \\
\hline & 40.26 & 10.87 & .76 & $0-75$ & $10-64$ & -.88 \\
\hline
\end{tabular}


Table 2

Demographic Characteristics of Students of Settled Area and FATA $(\mathrm{N}=211)$

\begin{tabular}{|c|c|c|c|c|c|}
\hline \multirow[t]{2}{*}{ Variable } & \multirow[t]{2}{*}{$\mathrm{N}(\%)$} & $\begin{array}{c}\text { Settled } \\
\text { Area }\end{array}$ & FATA & \multirow[t]{2}{*}{$x^{2}$} & \multirow[t]{2}{*}{ OR } \\
\hline & & $(\mathrm{n}=100)$ & $(n=100)$ & & \\
\hline \multicolumn{6}{|l|}{ Gender } \\
\hline Male & $130(65)$ & $49(37.7)$ & $81(62.3)$ & $22.50 * * *$ & .22 \\
\hline Female & $70(35)$ & $51(72.9)$ & $19(27.1)$ & & \\
\hline \multicolumn{6}{|c|}{ Marital Status } \\
\hline Married & $6(3)$ & $2(33.3)$ & $4(66.7)$ & $.68 * * *$ & .49 \\
\hline Unmarried & 194(97) & $96(49.5)$ & & & \\
\hline \multicolumn{6}{|c|}{ Family System } \\
\hline Joint & $110(55)$ & $48(43.6)$ & $62(56.4)$ & $3.96^{*}$ & 1.76 \\
\hline Nuclear & $90(45)$ & $52((57.8)$ & $38(42.2)$ & & \\
\hline
\end{tabular}

Table 2 shows distribution of gender, marital status and family system of students belongs to settled area and FATA. Gender distribution of students is highly significant $(\mathrm{p}<.001)$. Result table shows that greater number of male students belongs to FATA participated in the study as compare to female students and chi square revealed statistically significant difference. Most of the study participants are unmarried. Result table indicated that greater number of students belongs to FATA lived in joint family system as compared to students of settled area and value of chi square reveals significant difference $p<.05$.

Table 3

Mean Difference and t-Value of Students on Impact of Event Scale $(\mathrm{N}=200)$

\begin{tabular}{|c|c|c|c|c|c|c|c|c|}
\hline \multicolumn{2}{|c|}{$\begin{array}{c}\text { FATA } \\
(n=100)\end{array}$} & \multicolumn{2}{|c|}{$\begin{array}{l}\text { Settled Area } \\
(n=100)\end{array}$} & \multirow{3}{*}{$\mathrm{t}(198)$} & \multirow{3}{*}{$\mathrm{p}$} & & & \multirow{3}{*}{$\begin{array}{c}\text { Cohen's } \\
\text { D }\end{array}$} \\
\hline \multirow{2}{*}{$\mathrm{M}$} & \multirow{2}{*}{ SD } & \multirow{2}{*}{$\mathrm{M}$} & \multirow{2}{*}{ SD } & & & \multicolumn{2}{|c|}{ CI $95 \%$} & \\
\hline & & & & & & $\mathrm{LL}$ & UL & \\
\hline 40.26 & 10.87 & 34.76 & 10.47 & 3.64 & .001 & 2.52 & 8.48 & 0.52 \\
\hline
\end{tabular}


Table 3 shows mean difference between students of settled area and FATA on impact of event scale. The result shows that students of FATA scored higher than the students of settled area on impact of event scale. The Mean difference 5.50 is highly statistically significance $(\mathrm{p}<.001)$. Cohen's d value 0.52 shows high effect size.

Table 4

Frequency of Traumatic Events of Students on Impact of Event Scale $(\mathrm{N}=200)$

\begin{tabular}{lccc}
\hline Traumatic Event & $\begin{array}{c}\text { Settled Area } \\
(\mathrm{n}=100)\end{array}$ & $\begin{array}{c}\text { FATA } \\
(\mathrm{n}=100)\end{array}$ & $\begin{array}{c}\text { Total } \\
(\mathrm{n}=200)\end{array}$ \\
\hline $\begin{array}{l}\text { No event } \\
\text { War, Terrorism, Army }\end{array}$ & $27(27)$ & $26(22.3)$ & $53(26.5)$ \\
$\begin{array}{l}\text { operation } \\
\text { Academic problems }\end{array}$ & $33(33.0)$ & $30(30.0)$ & $63(31.5)$ \\
Family problems & $16(6.0)$ & $5(5.0)$ & $21(10.5)$ \\
Health related issues & $6(6.0)$ & $9(9.0)$ & $15(7.5)$ \\
$\begin{array}{l}\text { Minor issues of daily life } \\
\text { Death of close one's }\end{array}$ & $7(7.0)$ & $6(6.0)$ & \\
\hline
\end{tabular}

Table 4 shows frequency of traumatic events on impact of event scale. Fifty-three $(26.5 \%)$ students not report any traumatic event including students of settled area $27(27.0 \%)$ and FATA students $26(22.3 \%)$. War, terrorism, army operation in their area and other traumatic event report $63(31.5 \%)$ by students, including $30(30.0 \%)$ by students of settled area and 33(33.0\%) by students of FATA. Frequency of army public school attack as a traumatic event 21(10.5\%). And frequency of academic related problems, family problems, health related issues and minor issues of daily life are 14(7.0\%), 15(7.5\%), 13(6.5\%) and $8(4.0 \%)$ respectively. Result reveals that greater number of FATA students $33(33.0 \%)$ report war, terrorism, army operation in their area and other traumatic event.

\section{Discussion}

The findings of this study support our hypotheses. Result of this study reveals that the impact of event is high on directly affected (FATA) students as compare to students of settled area. Analysis for t-test shows 
statistically highly significant difference. These findings are in line with some previous studies, which shows that the impact of event was high on eyewitness and directly affected people of traumatic event and were suffered from severe psychological problems (Ahmad, Mohammad, Ahmed and Sajid, 2014; Korinek, Loebach, \& Teerawichitchainan, 2016). As Nijdam, Gersons, and Olff (2010) study findings indicate those who were more expose to terrorist attacks had posttraumatic stress disorder as compared to other people. (Nasim, Khan, \& Aziz, 2014). Schlenger et al. (2002) study showed strong association of psychological problems with direct exposure to terrorist attacks. Exposure to traumatic event and war strongly associated with stress related symptoms. (Zysberg, Kimhi, \& Eshel, 2013)

Hobfoll, Canetti-Nisim \& Johnson conducted a study on terrorism in (2006) and finding of that study suggested that post traumatic stress and other psychological problems were associated significantly with exposure to terrorism. Lamb and Kwok (2016) and Ross study finding reveals the high impact of interpersonal stress related to students' life. Environmental stressors have greater impact on individual health (Grandjean et al. 2015).

\section{Conclusion}

The present study showed that the impact of event was high on directly affected (FATA) students as compared to students of settled area. The result of t-test showed that there was significant difference among students of FATA and settled area on impact of event and perceived higher level of stress.

\section{Limitation}

Various limitations may exist in this study. First of all there is also security measure taken by govt. and restricted from general travel.

Other limitations include;

1. Generalizability of findings due to small sample size

2. Convenient sampling technique was used 
3. Large numbers of FATA students were from one area of FATA

4. University Students with age range 18-23 were included in the study.

\section{Suggestions and Recommendations}

Following are the few suggestions and recommendations for further studies

1. Large sample size could improve the generalizability of the findings of the study

2. Others areas of FATA should also be included.

3. Policy maker should make policies for such effected students.

4. Qualitative research studies for in-depth information regarding issues related to students of FATA.

5. Students of different age groups and general population should be taken for future studies.

\section{References}

Ahmad, S., Mohammad, H., Ahmed, S., \& Sajid, I. A. (2014). Gender Differences in Depression Among the Affectees of War on Terrorism and the Role of Psychological Interventions in the Rehabilitation. Pakistan Journal of Criminology, 6(2), 95112.Retrieved from: http:/www.pakistansocietyof criminology.com/publications/2015_03_28_3310.pdf\#page $=102$

Badri, A., Van den Borne, H. W., \& Crutzen, R. (2013). Experiences and psychosocial adjustment of Darfuri female students affected by war: An exploratory study. International journal of psychology, 48(5), 944-953. Retrieved on: 18, Dec 2014. Retrieved from: http://www.tandfonline. com/ doi/abs/10.1080/ 00207594.2012 .69 6652\#.VJMjWZveHIUCensus Data. (1998). Population census organization. Government of Pakistan. Retrieved from: http://census.gov.pk/ Demographic 
Indicator.htm Coping with trauma, terrorism \& war. (2014). University at Buffalo.The state university of New York. Buffalo, NY. 14261-0053. Retrieved from: http://www.studentaffairs.buffalo.edu /shs/ccenter/terrguide. php Education important factor in a developing country. UK ESSAYS. Retrieved from: http://www. ukessays.com/essays/education/ education-important-factor-in-a-developing-country-educationessay.php

Faizunnisa, A., \&Ikram, A. (2004). Determinants of Youth Development in Pakistan. Lahore Journal of Economics,9(2), 119-133. Retrieved from: http://121.52.153.179/JOURNAL/ Special \%20 Edition\%202008/ www root/JOURNAL/vol 9NoII/Vol.9, No.2. pdf\#page $=125$

Fischer, D. J. (2013). Stress. Columbia center for psychiatry. Retrieved from: http:/www.columbiapsychiatry.com/stress.html

Grandjean, P., et al. (2015). Life-long implications of developmental exposure to environmental stressors: new perspectives. Endocrinology, 156(10), 3408-3415. Retrieved from: http://press. endocrine.org/doi/abs/10.1210/EN.2015 -1350

Hilali, A. Z. (2013). Contemporary Geopolitics of FATA: An Analysis of the Afghanistan-Pakistan Border Region. The Journal of Slavic Military Studies,26(4), 595-638. Retrieved from:http://www.tand fonline.com /doi/abs/10.1080/ 13518046.2013.8 44502\#.VIvT4 pveHIU

Jaykaran, P. Y., Bhardwaj, P., Panwar, A., \& Chavda, N. (2009). Perception of faculties regarding the stress in medical educationa qualitative study. The Internet Journal of Epidemiology, 7(1).Retrieved from: https://ispub.com/ IJE/7/1/12791

Korinek, K., Loebach, P., \& Teerawichitchainan, B. (2016). Physical and Mental Health Consequences of War-related Stressors Among Older Adults: An Analysis of Posttraumatic Stress Disorder and Arthritis in Northern Vietnamese War Survivors. The Journals of Gerontology Series B: Psychological Sciences and Social Sciences, gbv157. Retrieved from: 
http://psychsocgerontology.oxfordjournals.org/content/early/201 6/01/11/geronb.gbv157.abstract

Lamb, S., \& Kwok, K. C. S. (2016).A longitudinal investigation of work environment stressors on the performance and wellbeing of office workers. Applied Ergonomics, 52, 104-111.Retrieved from: http:/www. sciencedirect.com/science/ article/pii/S08971897150 01731

Nijdam, M. J., Gersons, B. P., \&Olff, M. (2010). Dutch politicians' coping with terrorist threat. The British Journal of Psychiatry, 197(4), 328-329. Retrieved from: http://bjp.rcpsych. org/content/193/2/165.short

Schlenger, W. E., Caddell, J. M., Ebert, L., Jordan, B. K., Rourke, K. M., Wilson, D \& Kulka, R. A. (2002). Psychological reactions to terrorist attacks: findings from the National Study of Americans' Reactions to September 11. Jama, 288(5), 581-588. Retrieved from: http://jama.jamanetwork.com/ article.aspx?articleid $=195165$ \&resultclick $=1$

Shaikh, B. T., et al. (2004). Students, stress and coping strategies: a case of Pakistani medical school. Education for Health-AbingdonCarfax Publishing Limited, 17, 346-353. Retrieved from: https://www.research gate.net/profile/ Babar_ Shaikh/publication/7888674_Students_stress_and_coping_strate gies_A_case_of_Pakistani_medical_school/links/02bfe50ff750d 1b06c000000.pdf

Stress. (2015). Merriam-Webster Online. In Marriam-Webster. Retrieved Webster. Retrieved February 28, 2016, from: http://www.merriam-webster.com/ dictionary/stress

Timby, B. K. (2008). Fundamental nursing skills and concepts. USA, Philadelphia, Lippincott Williams \& Wilkins press: P. 941. Retrieved from: http://books.google.com.pk /books? hl=en\&lr= \&id=M4HwH5 IxfToC\&oi =fnd\&pg=PA1\&dq=. Fundamental + Nursing + Skills + and + Concepts.\&ots $=y g N W$ JOk19C\&sig=yVG8F784d3EhvQMCi3yxn3kUFtM\#v=onepage 
$\& q=$. Fundamental $\% 20$ Nursing $\% 20$ Skills $\% 20$ and $\% 20$ Concepts.

$\& \mathrm{f}=$ false

Zysberg, L., Kimhi, S., \& Eshel, Y. (2013). Someone to watch over me: Exposure to war events and trust in the armed forces in Israel as factors in war-related stress. Medicine, Conflict and Survival, 29(2), 140-154. Retrieved from :http://www.tandfonline.com/ doi/abs/10.1080/13623699.2013.785 109\#.VsnQ2xDmqX8 